\title{
Phylogenetic Relationship of Mangosteen (Garcinia mangostana) and Several Wild Relatives (Garcinia spp.) Revealed by ITS Sequence Data
}

\author{
Chinawat Yapwattanaphun and Suranant Subhadrabandhu ${ }^{1}$ \\ Department of Horticulture, Faculty Agriculture, Kasetsart University, Bangkok, 10900, Thailand \\ Chitose Honsho and Keizo Yonemori ${ }^{2}$ \\ Graduate School of Agriculture, Kyoto University, Sakyo-ku, Kyoto, 606-8502, Japan
}

AdDitional IndeX wORDs. Garcinia, taxonomy, polyploidy, hybridism, internal transcribed spacer

\begin{abstract}
The phylogenetic relationships among 17 Garcinia species including $G$. mangostana (mangosteen) were analyzed by comparing sequences of the internal transcribed spacer (ITS) region of nuclear ribosomal DNA (nrDNA). Both parsimonious and neighbor joining (NJ) analyses revealed that $G$. mangostana is closely related to $G$. malaccensis believed to be a progenitor of mangosteen. Another suspected progenitor of mangosteen, G. hombroniana, was more distant from $G$. mangostana than G. malaccensis phylogenetically. Garcinia hombroniana formed a cluster with $G$. rostrata, $G$, specios $a$ and $G$. sizygiifolia, and this cluster was connected with a cluster of $G$. mangostana and $G$. malaccensis. The ITS sequence analysis showed that G. atroviridis, G. cowa, G. dulcis, G. malaccensis, G. mangostana, $G$. rostrata and $G$. vilersiana have nucleotide additivity (two different nucleotides at the same nucleotide position) at several sites in the ITS region. The occurrence of these species might be related to hybridization with ancestors, but the genomic compositions, even chromosome numbers, of these species are still unknown.
\end{abstract}

Mangosteen (Garcinia mangostana L.) is a well-known tasty tropical fruit with attractive fruit shape and color. It is reported to have originated in southeast Asia and is famed as the 'queen of tropical fruit'. Many visitors to southeast Asia enjoy this sweet and juicy fruit. In addition to its use as a dessert, the dried fruit rind, which contains tannin and xanthones, is also used for treatment of inflammations, diarrhea, and dysentery in native medicine (Yapwattanaphun et al., 2002). Mangosteen is one of the most important economic fruit crops in Thailand, and the demand of mangosteen fruit usually exceeds the supply (Richard, 1990a; Yaacob and Tindall, 1995).

Mangosteen reproduction is very interesting because only female trees have been found. Since mangosteen is apomictic, all mangosteen trees are thought to be clones with the same genotype. Richard (1990b) reported that G. mangostana is allopolyploid and derived from the hybridization of G. hombroniana and G. malaccensis. He reported that 13 important morphological characteristics of G. mangostana are intermediate between G. hombroniana and G. malaccensis. However, his hypothesis has not been confirmed by analytical methods using molecular techniques. The origin of mangosteen is still unclear, although it is a very important fruit crop in southeast Asia.

Mangosteen belongs to the genus Garcinia, and many Garcinia species are distributed in southeast Asia. In the tropical forest in Thailand, there are 22 reported Garcinia species (Smitinand, 1980). Several of the species are important for commercial use such as timber, resin, or various natural products, in addition to the production of edible fruit. However, information on genetic diversity and phylogenetic relationships of these species to $G$. mangostana (mangosteen) is very limited. (Yaacob and Tindall, 1995; Yapwattanaphun et al., 2002).

Received for publication 19 June 2003. Accepted for publication 18 Nov. 2003. This work was supported, in part, by The Royal Golden Jubilee PhD program of the Thailand Research Fund.

${ }^{1}$ Deceased 16 July 2003.

2Corresponding author; e-mail keizo@kais.kyoto-u.ac.jp.
Sequence analysis of internal transcribed spacer (ITS) region of nuclear ribosomal DNA (nrDNA) between the small subunit $(18 \mathrm{~S})$ and the large subunit (26S) of nrDNA has been used as a source for analysis of phylogenetic relationships within genera and among closely related genera in many angiosperms (Baldwin et al., 1995). It frequently has been used to resolve phylogenetic relationships among many plant taxa, such as Coffea spp. (Lashermes et al., 1997), Glycine spp. (Kollipara et al., 1997), Allium spp. (Dubouzet and Shinoda, 1998), Asarum (Kelly, 1998), Artemisia (Kornkven et al., 1998), Loasaceae (Moody et al., 2001), and Mangifera (Yonemori et al., 2002). In this study we used a sequence analysis of ITS region of nrDNA between the small subunit and the large subunit of nrDNA to describe the relationship among Garcinia species to provide fundamental information for the breeder, because it will be important for genetic improvement of mangosteen in the future.

\section{Materials and Methods}

Plant material and DNA extraction. Seventeen species of Garcinia and some accessions were collected from Thailand, Indonesia, Malaysia and Australia (Table 1). Mammea siamensis and Calophyllum inophyllum were selected as outgroup taxa. These two species belonged to the same family as Garcinia, the family Guttiferae, and $M$. siamensis was selected because it was easy to obtain in Thailand and C. inophyllum because it was morphologically close to Garcinia.

For DNA extraction, $5 \mathrm{~g}$ of leaf tissue were ground into a powder with liquid nitrogen in a mortar. The cetyltrimethyl ammonium bromide (CTAB) method reported by Doyle and Doyle (1987) was used for DNA isolation with a slight modification as described by Schnell et al. (1995). The isolated DNA was purified by precipitating with a polyethylene glycol (PEG) solution (Helig et al., 1992). Then, DNA was quantified by visual comparison with a DNA standard under UV light following electrophoresis on a $1 \%$ agarose gel and stained with $50 \mathrm{ppm}$ of ethidiumbromide 
for $30 \mathrm{~min}$. The DNA concentration was adjusted with Tris-EDTA (TE) buffer (pH8.0) to $\approx 50 \mathrm{ng} \cdot \mu \mathrm{L}^{-1}$.

AMPLIFICATION AND SEQUENCING OF ITS REgION. The entire ITS region, including the 5.8S nrDNA coding region, was amplified by PCR using primers ITS-4 and ITS-5 (White et al., 1990). Reaction mixtures $(100 \mu \mathrm{L})$ contained $10 \mathrm{~mm}$ Tris- $\mathrm{HCl}(\mathrm{pH} 8.3)$, $50 \mathrm{~mm} \mathrm{KCl}, 1.5 \mathrm{~mm} \mathrm{MgCl}_{2}, 5 \%$ glycerol, $0.2 \mathrm{~mm}$ each dNTP, 25 pmol of each primer, 20 to $40 \mathrm{ng}$ genomic DNA and 5 units of TaKaRa $r$ Taq DNA polymerase (TaKaRa Shuzo Co. Ltd., Shiga, Japan). Amplification was carried out in a TaKaRa PCR Thermal Cycler MP (TP3000; TaKaRa Shuzo Co., Ltd., Shiga, Japan) for 5 min at $98^{\circ} \mathrm{C}$, followed by 35 cycles of $1 \mathrm{~min}$ at $97^{\circ} \mathrm{C}, 30 \mathrm{~s}$ at $57{ }^{\circ} \mathrm{C}$ and 1.5 min at $72{ }^{\circ} \mathrm{C}$, with a final run of 7 min at $72{ }^{\circ} \mathrm{C}$. The amplified products were then purified through a spin column (SUPREC-02; TaKaRa Shuzo Co. Ltd., Shiga, Japan) for direct sequencing.

Forward and reverse sequencing reactions were performed using a Big Dye Terminator ver.3 Cycle Sequencing Ready Reaction Kit (Applied Biosystems, Perkin Elmer, Foster City, Calif.) using ITS-2 and ITS-5, and ITS-3 and ITS-4 (White et al., 1990) as sequencing primers for ITS1 and ITS2 regions, respectively. Sequencing reactions were done according to the standard protocol provided by Perkin Elmer with the kit. Sequence analysis was performed with an automated DNA sequencer (ABI PRISM 310 Genetic Analyzer; Applied Biosystems, Perkin Elmer, Foster City, Calif.) after the extra fluorescent ddNTPs were removed with Centri-Sep Spin Columns (Applied Biosystems, Perkin Elmer, Foster City, Calif.).

SEquence alignment. Sequence data of the ITS1, 5.8S, and ITS2 regions were first aligned by using GENETYX-MAC 7.3 (Software Development Co. Ltd., Tokyo, Japan), and then the alignment was checked and slight modifications made manually. The boundaries of ITS1 and ITS2 were determined by compar- ing the aligned sequence with previously published sequences (Baldwin 1992; Kollipara et al., 1997; Lashermes et al., 1997). The 5.8S coding sequence was also considered for phylogenetic analysis, although only a few variations were found among the species examined.

Phylogenetic analysis. The aligned sequence data matrix was analyzed by a PAUP 4.0b10 program (Swofford, 2002) by treating the gap as fifth base. Unordered parsimony analysis with accelerated transformation (ACCTRAN) optimization was performed by a heuristic search procedure with simple for stepwiseaddition options, options of tree-bisection-reconnection (TBR) branch swapping, and saving the multiple trees (MulTrees). The most parsimonious trees were also found by a heuristic search procedure. In addition, bootstrap analysis with 250 replications was conducted to assess the degree of support for each branch with consensus tree option of retaining group with frequency $>50 \%$. In the analysis, two outgroup taxa were used to root the tree. The phylogenetic reconstruction was also performed by neighbor-joining (NJ) method (Saitou and Nei 1987) with PHYLIP (Felsenstein, 1993) after the distance matrices were calculated by the Kimura 2-parameter model of Dnadist in PHYLIP v.3.57 (Felsenstein, 1993). In the analysis, the polymorphic site from additivity having a nucleotide and a gap was treated as a gap at this site, since we could not define the site for this kind of additivity in PHYLIP. NJ tree was drawn by a Tree Draw Deck hacked into Hypercard (Gilbert, 1990) from Drawgram and Drawtree programs of the PHYLIP.

\section{Results}

ITS SEQUENCING. The entire ITS region in Garcinia species ranged from 616 to $621 \mathrm{bp}$ (Table 2). The length of ITS1 region was 254 to $257 \mathrm{bp}$ and of ITS2 was 199 to $202 \mathrm{bp}$. There is no

Table 1. List of Garcinia species and two outgroup taxa with their collected place.

\begin{tabular}{|c|c|c|}
\hline Species & Collection place & Accession no. \\
\hline G. costata & Ubon Ratchathani, Thailand & AB110798 \\
\hline G. dulcis accession 1 & Ubon Ratchathani, Thailand & AB 110800 \\
\hline G. dulcis accession 2 & Bangkok, Thailand & AB110801 \\
\hline G. hanburyi & Chantaburi, Thailand & AB110802 \\
\hline G. malaccensis accession 1 & Bogor, Indonesia & AB110805 \\
\hline G. malaccensis accession 2 & Bogor, Indonesia & AB110806 \\
\hline G. mangostana accession 1 & Bogor, Indonesia & AB 110807 \\
\hline G. mangostana accession 2 & Nakon Srithammarat, Thailand & AB110809 \\
\hline G. mangostana accession 3 & Narathiwat, Thailand & AB 110810 \\
\hline G. schomburgkiana & Bangkok, Thailand & AB 110814 \\
\hline G. sizygiifolia & Bogor, Indonesia & AB 110815 \\
\hline G. speciosa & Bangkok, Thaikand & AB110816 \\
\hline G. tinctoria & Brisbane, Australia & AB 110817 \\
\hline G. vilersiana & Chantaburi, Thailand & AB110818 \\
\hline G. xanthocymus & Chiang Mai, Thailand & AB110819 \\
\hline Calophyllum inophyllum & Bangkok, Thailand & AB110820 \\
\hline Mammea siamensis & Bangkok, Thailand & AB110821 \\
\hline
\end{tabular}


Table 2. The characteristic features of the ITS region among Garcinia species plus two outgroup taxa.

\begin{tabular}{|c|c|c|c|c|c|c|c|c|c|c|c|c|c|}
\hline Species & $\begin{array}{l}\text { Length } \\
\text { range } \\
\text { (nt) }\end{array}$ & $\begin{array}{l}\text { Length } \\
\text { mean } \\
(\mathrm{nt})\end{array}$ & $\begin{array}{l}\text { Aligned } \\
\text { length } \\
\text { (nt) }\end{array}$ & $\begin{array}{c}\mathrm{G}+\mathrm{C} \\
\text { content } \\
(\%)\end{array}$ & $\begin{array}{c}\mathrm{G}+\mathrm{C} \\
\text { mean } \\
(\%)\end{array}$ & $\begin{array}{c}\text { No. } \\
\text { of } \\
\text { indels }\end{array}$ & $\begin{array}{c}\text { No. of } \\
\text { variable } \\
\text { sites }\end{array}$ & $\begin{array}{c}\text { No. of } \\
\text { informative } \\
\text { sites }\end{array}$ & $\begin{array}{c}\text { No. of } \\
\text { maximally } \\
\text { parsimonious } \\
\text { tree }\end{array}$ & $\begin{array}{c}\text { Tree } \\
\text { length }\end{array}$ & $\begin{array}{l}\text { Consistency } \\
\text { index } \\
\text { (CI) }\end{array}$ & $\begin{array}{c}\text { Retention } \\
\text { index } \\
(\mathrm{RI})\end{array}$ & $\begin{array}{c}\text { Rescaled } \\
\text { consistency } \\
\text { index } \\
\text { (RC) }\end{array}$ \\
\hline \multicolumn{14}{|l|}{ Garcinia } \\
\hline ITS1 & $254-257$ & 255.41 & 261 & $47.65-52.94$ & 51.38 & 7 & 93 & 81 & 128 & 132 & 0.8258 & 0.9475 & 0.7824 \\
\hline $5.8 \mathrm{~S}$ rDNA & 163 & 163 & 163 & $50.31-52.15$ & 51.48 & 0 & 3 & 3 & 3 & 3 & 1.0000 & 1.0000 & 1.0000 \\
\hline ITS2 & 199-202 & 199.70 & 202 & $49.50-52.76$ & 51.15 & 4 & 83 & 68 & 127 & 127 & 0.8740 & 0.9498 & 0.8302 \\
\hline Entire sequence & $616-621$ & 618.12 & 626 & $49.59-52.51$ & 51.33 & 11 & 179 & 152 & 263 & 264 & 0.8447 & 0.9466 & 0.7996 \\
\hline \multicolumn{14}{|c|}{ Garcinia + two outgroup taxa } \\
\hline ITS1 & $236-259$ & 254.80 & 261 & $47.66-73.30$ & 52.45 & 27 & 216 & 138 & 357 & 357 & 0.8880 & 0.9279 & 0.8240 \\
\hline $5.8 \mathrm{~S}$ rDNA & 163 & 163 & 163 & $50.31-57.67$ & 51.81 & 0 & 14 & 8 & 16 & 16 & 1.0000 & 1.0000 & 1.0000 \\
\hline ITS2 & $172-202$ & 198.42 & 202 & $49.50-73.71$ & 52.36 & 36 & 177 & 127 & 329 & 336 & 0.8512 & 0.8879 & 0.7558 \\
\hline Entire sequence & $593-621$ & 616.23 & 626 & $49.59-69.13$ & 52.27 & 63 & 407 & 273 & 708 & 708 & 0.8743 & 0.9125 & 0.7978 \\
\hline
\end{tabular}

variation in length of $5.8 \mathrm{~S}$ gene region, which had $163 \mathrm{bp}$ (Table 2). In the two outgroups, the length of entire ITS region was 593 and 594 bp in C. inophyllum and M. siamensis, respectively. The lengths of ITS1 were 236 bp in C. inophyllum, much shorter than that in Garcinia species, and 259 bp in M. siamensis, almost the same as that in Garcinia species. The length of $5.8 \mathrm{~S}$ in both outgroup taxa was the same as that of Garcinia species. The length of ITS2 in C. inophyllum was almost the same as that in Garcinia species (194 bp), but it was very short in M. siamensis, having the length of $172 \mathrm{bp}$. As a result, the entire length of ITS region in $C$. inophyllum and M. siamensis was shorter than in Garcinia species.

The percentage $\mathrm{G}+\mathrm{C}$ content in the entire ITS region varied among the Garcinia species from $49.59 \%$ to $52.51 \%$. However, the $\mathrm{G}+\mathrm{C}$ content between ITS1 and ITS2 was fairly equivalent over the species (Table 2). The $\mathrm{G}+\mathrm{C}$ content was higher in two outgroup species than in Garcinia species. The $\mathrm{G}+\mathrm{C}$ content in entire ITS region was $69.13 \%$ in C. inophyllum and $57.74 \%$ in M. siamensis. The whole sequences obtained in the present study are accessible to DDBJ/EMBL/ GenBank with accession code AB110796 to AB110821 (Table 1).

According to the entire sequence alignment among Garcinia species, only 11 indels (seven in ITS1, four in ITS 2) were assumed and it resulted in $626 \mathrm{bp}$ in aligned length including $5.8 \mathrm{~S}$ gene region. There were 93 and 83 polymorphisms in ITS1 and ITS2, respectively, while only three sites were polymorphic sites in $5.8 \mathrm{~S}$ gene region (Table 2).

Fig. 1. The consensus tree for unordered PAUP analysis from 250 bootstrap replications with option retaining groups with frequency $>50 \%$ in TBR heuristic search. Numbers above branches indicate branch lengths drawn proportionally to the number of character-state changes. Numbers in parentheses show the percentage of occurrence of each monophyletic group from 250 bootstrap replication.

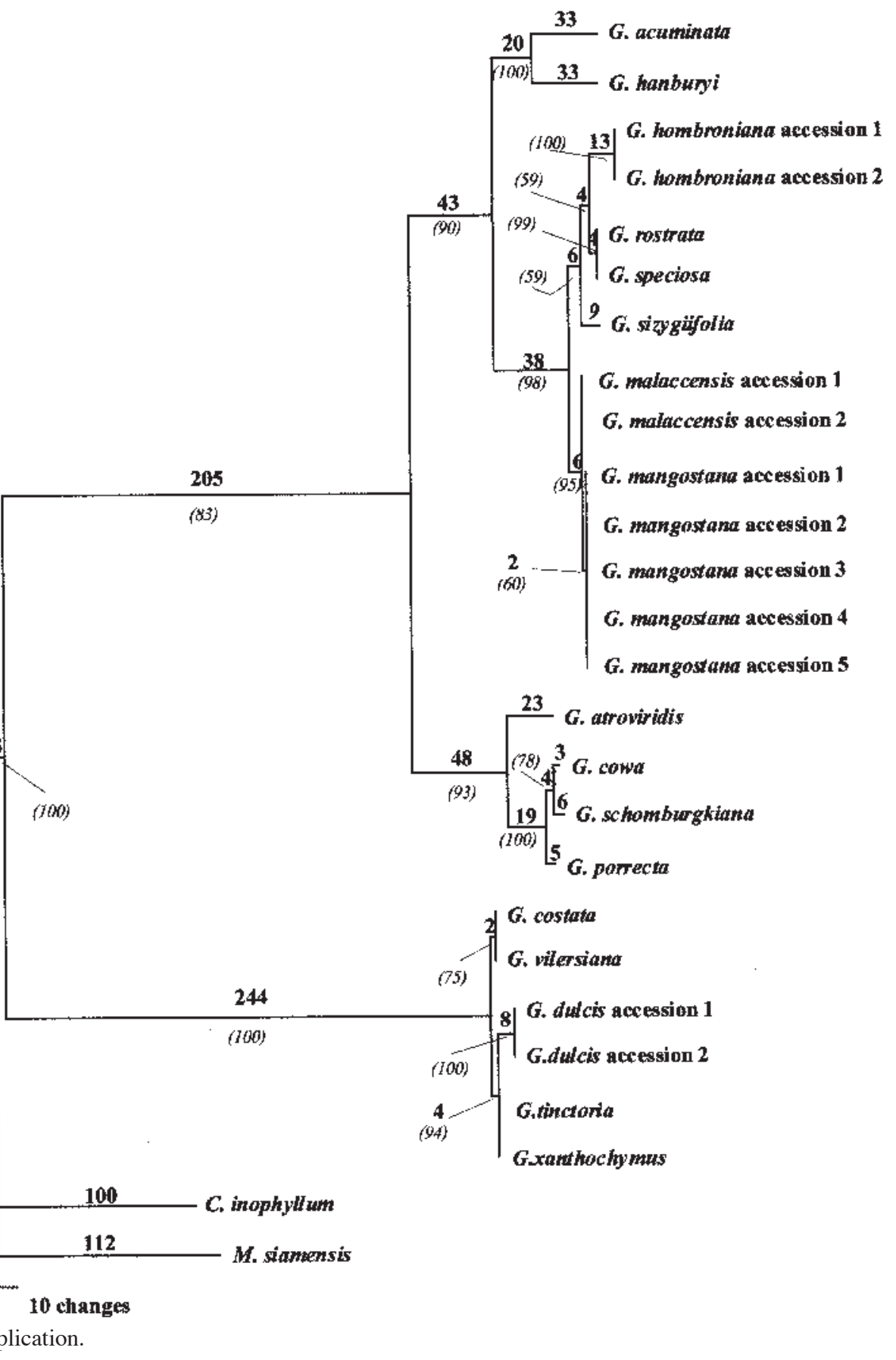




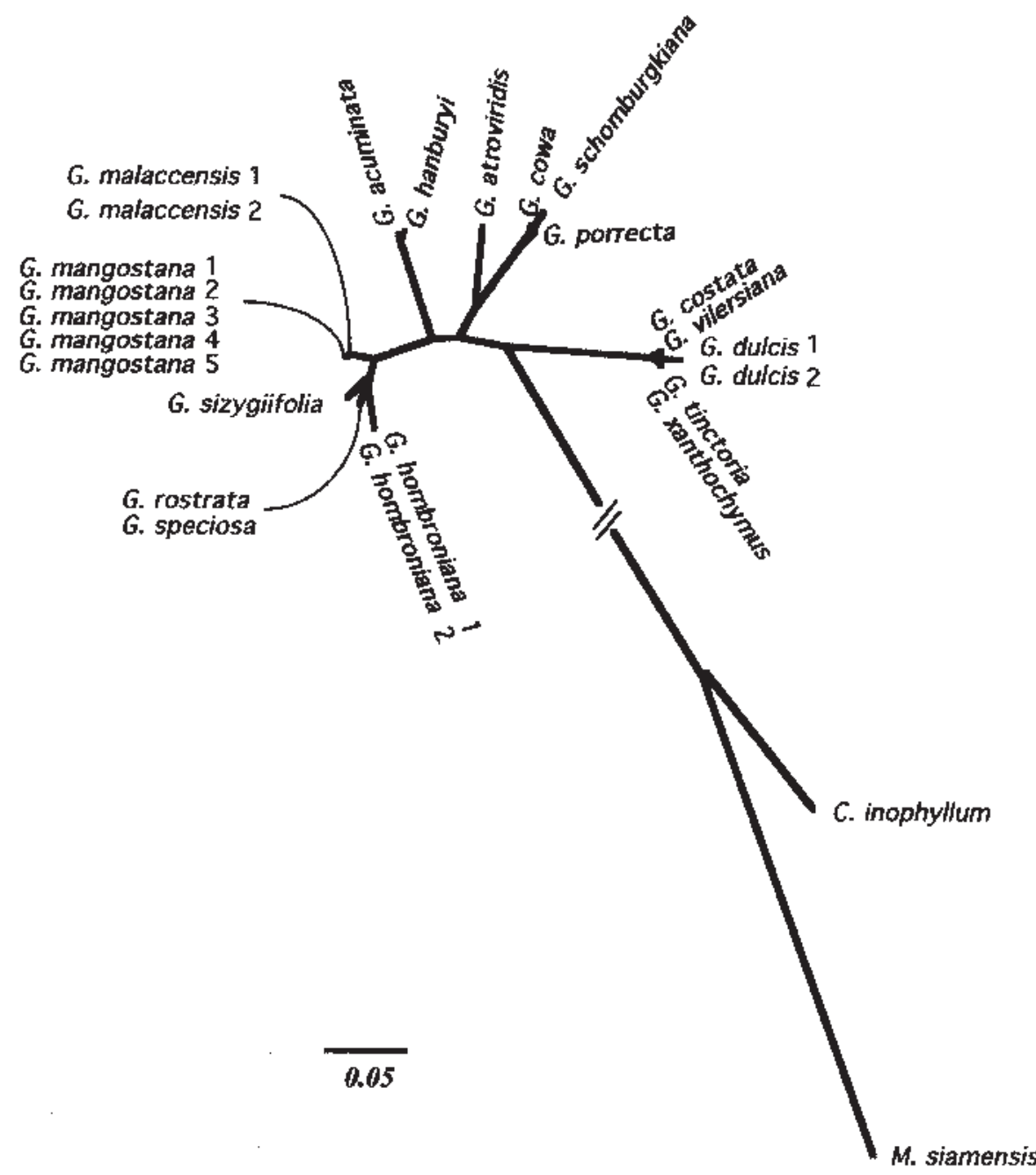

Fig. 2. Neighbor-joining tree obtained using the genetic distance of Kimura 2-parameter model of Dnadist in PHYLIP v.3.57 (1993).

However, when the sequence of two outgroup taxa were added to the alignment, the polymorphic sites were 216, 14, and 177 in ITS1, 5.8S, and ITS2, respectively. As a result, the polymorphic sites became 407 for the entire sequence in all species including outgroup taxa, and 273 sites among those were assumed to be informative for parsimonious analysis (Table 2).

In addition, we found nucleotide additivitiy in several species. Additivity, defined as having two different nucleotides at the same nucleotide position in the ITS region, was first used by Sang et al. (1995). The number of additivity sites was one in $G$. atroviridis, $G$. vilersiana, both accessions of $G$. malaccensis, and one accession of $G$. mangostana, and two in $G$. rostrata and both accessions of $G$. dulcis, and three in G. cowa.

However, despite the existence of additivity in some accessions, the sequence of the accessions of G. dulcis, G. hombroniana, or $G$. mangostana was completely the same, except for one accession of $G$. mangostana from Trat, which was different from the other four accessions showing additivity by having different nucleotides at only one position. Also, two accessions of G. malaccensis showed almost the same sequence between them, except for having different nucleotides in additivity site at two different positions.

Phylogenetic analysis. The results of parsimonious analysis based on sequence data of ITS region are also summarized in
Table 2. Using the entire sequence of the ITS region, parsimonious analysis revealed a very close relationship between $G$. mangostana and G. malaccensis (Fig. 1). Five accessions of $G$. mangostana were included in the same group because of less variations in the sequences and constituted a clade with G. malaccensis (Fig. 1). This relationship was true even in the strict consensus tree constructed from 250 bootstrap analyses (data not shown).

According to parsimonious analysis, $G$. hombroniana formed a group together with G. rostrata, G. speciosa, and G. sizygiifolia, and this group formed a large group with the clade of G. mangostana and G. malaccensis. (Fig. 1). The group of G. costata, G. vilersiana, $G$. dulcis, G. tinctoria and G. xanthochymus formed a separate group with other Garcinia species tested in this study. As for outgroup taxa, M. siamensis was more distantly related to $G$. mangostana than $C$. inophyllum.

The result of neighbor-joining (NJ) analysis was similar to that of parsimonious analysis, showing a close relationship between $G$. mangostana and G. malaccensis and a little genetic distance between $G$. mangostana and G. hombroniana (Fig. 2). Furthermore, in the NJ tree, G. costata, G. vilersiana, $G$. dulcis, G. tinctoria and G.xanthochymus were separated by outgroup taxa from the other 12 Garicinia species as in the result of parsimonious analysis, showing a different evolutionary process from the other 12 species including G. mangostana.

\section{Discussion}

The most interesting feature of ITS sequence found in this study is the relationship among G. mangostana, G. malaccensis and G. hombroniana. Garcinia mangostana formed a cluster with G. malaccensis, and this cluster was joined with a cluster of $G$. hombroniana, G. rostrata and G. speciosa. According to the study on morphological characteristic of these species, G. mangostana seems to be derived from $G$. malaccensis and $G$. hombroniana as allopolyploid (Richard, 1990b). Among 13 main characters (flowering time, latex color, petal color, stigma, stigma surface, stigma lobes, stigma diameter, stamen mass, female flower, fruit shape, fruit surface, fruit color, and fruit flavor), four characters (latex color, petal color, sessile stigma, and fruit color) of G. mangostana are similar to those of G. malaccensis and four characters (smooth stigma surface, stamen/staminode mass clearly lobed, fruit globose, surface smooth) to those of G. hombroniana. Another five characters (flowering time, depth of stigma lobes, stigma diameter, presence of staminodes in the female flower, and fruit taste) fell between the two species. There are no characters of $G$. mangostana which fell outside the range of variability of $G$. malaccensis and G. hombroniana. Thus, Richard (1990b) proposed that morphologically, G. mangostana is a hybrid between $G$. hombroniana and $G$. malaccensis. He also suggested that the mother of the original G. mangostana was a cultivated G. hombroniana and the father was a wild $G$. malaccensis occurring nearby. The chromosome number of G. mangostana was almost double 
that of G. malaccensis and G. hombroniana (Richard, 1990b), although the exact number of chromosome is still unidentified for $G$. mangostana and $G$. malaccensis. The ITS sequence in this study, however, showed that $G$. hombroniana was more distant from $G$. mangostana than $G$. malaccensis phylogenetically. It is possible that $G$. hombroniana is not a direct ancestor of $G$. mangostana. Since three other species, G. rostrata, G. speciosa and G. sizygiifolia, formed the same cluster as G. hombroniana, these species might be included in the origin of G. mangostana. The fruit of $G$. hombroniana is similar to that of $G$. mangostana and have a pleasant peach-like flavor (Ridley, 1922). The fruit of $G$. rostrata is also quite similar to that of $G$. hombroniana, but the latter is larger than the former and turns red when it ripens. Because G. rostrata, G. speciosa, and G. sizygiifolia are not economically fruit, important information on morphology and utilization of these species is very limited. We found $G$. rostrata in the eastern part of Thailand but it is not eaten as a fruit. Garcinia speciosa is a large tree with coriaceous and elliptic-lanceolate leaves. It has flowers with a pleasant smell and globose berry fruit $5 \mathrm{~cm}$ in diameter. The fruit skin turns bright red when ripe and the seeds are embedded in acidic pulp (Brandis, 1978). In Thailand, sweet-smelling flowers of G. speciosa are used as ornamental trees according to Thai's classical literature. Unfortunately, so far, there is no report on the relationship of these species to $G$. mangostana.

Another important result of our study is the finding of nucleotide additivity in ITS sequence among several species. This feature implies that there are two different templates with different base pairs at the same nucleotide position in the copies of ITS sequence in an organism, because we first used PCR amplicons as templates for direct sequencing. This allows us to assume the possibility of allopolyploidy by hybridization. Both parental sequences of the ITS region have been maintained in an allopolyploid species in Krigia (Kim et al., 1994), Paeonia (Sang et al., 1995) and Arabidopsis suecica (O'Kane et al., 1996) probably due to insufficient time for homogenizing parental ITS sequences by concerted evolution. We found additive sequences in G. atroviridis, G. cowa, G.dulcis, G. malaccensis, G. mangostana, $G$. rostrata, and G. vilersiana. As for G. mangostana, additivity may be caused by the allopolyploidy of their origin. However, we found additivity in only one accession from Trat, in which there is a site having $\mathrm{T}$ and $\mathrm{C}$ in the ITS 1 region. In our previous study on genetic variation in 23 accessions of $G$. mangostana by AFLP analysis, polymorphisms were detected in the same accession of G. mangostana from Trat (Yapwattanaphun et al., 2003). It is unclear why the additivity was found in this study. However, since the basic chromosome number of Garcinia species is not known and the ploidy of these species is not elucidated, there is a possibility that these species are of hybrid origin.

The relationship of relatively important species for commercial use was also shown in this study. Garcinia atroviridis and G. schomburgkiana are important species in Thailand. Garcinia atroviridis has a big fruit and is claimed to be efficacious in health promotion such as reducing cholesterol in blood, enlarging the blood vessel, and absorbing the excess fat. Dried fruit of $G$. atroviridis is used for improvement of blood circulation, as an expectorant, for treatment of coughs, and as a laxative (Yapwattanaphun et al., 2002). In Thailand, a lot of G. atroviridis products are sold in the market, such as tea, capsule and fruit's slice. Garcinia schomburgkiana also grows wild near streams and swamps in dry evergreen forests, and is sometimes cultivated in home gardens. The young leaf of G. schomburgkiana is served as a vegetable accompaniment in many Thai dishes and can be eaten either raw or cooked. The fruit is rich in vitamin A and calcium and is eaten fresh, but it is very sour. It can be used in a sauce with shrimp paste and chili that is eaten with vegetables and fish. The fruit of G. schomburgkiana can also be processed as preserved fruit in syrup, pickled fruit, and dried fruit (Yapwattanaphun et al., 2002). Young leaves of $G$. cowa are used as a food additive in southeast Asia. In this study, these three species have formed a cluster with $G$. porrecta, which was apart from a large cluster involving G. mangostana. These commercially important species are not closely related to $G$. mangostana.

In addition, the young shoot and mature fruit of G. xanthochy$m u s$, which is native to the Philippines and Indonesia, are eaten as a vegetable and fruit in Indonesia, Malaysia, Thailand and the Philippines. Garcinia dulcis is sometimes sold as edible fruit in the local markets in Thailand and Malyasia. Fruit of G. dulcis is spheroid shaped and turns orange when ripe. The seeds are enveloped in edible pulp of a darker color than the skin and have a pleasant taste. Garcinia xanthochymus and G. dulcis formed a cluster with $G$. costata, $G$. tinctoria, and $G$. vilersiana, and this cluster is clearly separated from $G$. mangostana, showing a different evolutionally process from $G$. mangostana. In this study, we used $G$. tinctoria, which was collected in Australia and has been said to be a synonym of $G$. xanthochymus. We found that these two species had the same ITS sequence, confirming that they were synonyms.

Overall, ITS sequence analysis of mangosteen and the several wild relatives used in this study gave us new information on the phylogenetic relationship among the species. This information will provide useful ideas for the improvement of the crop and further development and cultivation of it in the near future. Also, the usefulness of ITS sequence analysis for phylogenetic study was clearly demonstrated in this study.

\section{Literature Cited}

Baldwin, B.G. 1992. Phylogenetic utility of the internal transcribed spacers of nuclear ribosomal DNA in plant: An example from the Compositae. Mol. Phylogenet. Evol. 1:3-16.

Baldwin, B.G., M.J. Sanderson, J.M. Porter, M.F. Wojciechowski, C.S. Campbell, and M.J. Donoghue. 1995. The ITS region of nuclear ribosomal DNA : A valuable source of evidence on angiosperm phylogeny. Ann. Missouri Bot. Gard. 82:247-277.

Brandis, D. 1987. Indian tree. Perdical Experts Book Agency, Delhi. Doyle, J.J. and J.L. Doyle. 1987. A rapid DNA isolation procedure for small quantities of fresh leaf tissue. Phytochem. Bul. 19:11-15.

Dubouzet, J.G. and K. Shinoda. 1998. Phylogeny of Allium L. subg. Melanocrommyum (Webb et Berth.) Rouy based on DNA sequence analysis of the internal transcribed spacer region of nrDNA. Theor. Appl. Genet. 97:541-549.

Felsenstein, J. 1993. PHYLIP (Phylogeny Inference Package) version 3.57. Distributed by the author. Dept. Genet., Univ. Wash., Seattle.

Gilbert, D.G. 1990. Tree draw deck. Distributed by the author. Biol. Dept., Ind. Univ., Indianapolis.

Helig, S.S., K. Lech, and R. Brent. 1992. PEG precipitation, p.123-124. In F.M. Ausubel, R. Brent, R.E. Kingston, D.D. Moore, J.G. Seidman, J.A. Smith, and K. Struhl (eds.). Short protocols in molecular biology. 2nd ed. Wiley, New York.

Kelly, L.M. 1998. Phylogenetic relationship in Asarum (Aristolochiaceae) based on morphology and ITS sequence. Amer. J. Bot. 85: 1454-1467.

Kim, K.-J. 1994. Comparisons of phylogenetic hypothesis among different data sets in dwarf dandelions (Krigia, Asteraceae): Additional information from internal transcribed spacer sequences of nuclear ribosomal DNA. Plant Syst. Evol. 190:157-185. 
Kollipara, K.P., R.J. Singh, and T. Hymowitz. 1997. Phylogenetic and genomic relationships in the genus Glycine Willd. based on sequences from the ITS region of nuclear rDNA. Genome 40:57-68.

Kornkven, A.B., L.E. Watson, and J.R. Estes. 1998. Phylogenetic analysis of Artemisia section Tridentatae (Asteraceae) based on sequences from the internal transcribed spacers (ITS) of nuclear ribosomal DNA. Amer. J. Bot. 85:1787-1795.

Lashermes, P., M.C. Combes, P. Trouslot, and A. Charrier. 1997. Phylogenetic relationship of coffee-tree species (Coffea L.) as inferred from ITS sequences of nuclear ribosomal DNA. Theor. Appl. Genet. 94: 947-955.

Moody, M.L., L. Hufford, D.E. Soltis, and P.S. Soltis. 2001. Phylogenetic relationship of Loasaceae subfamily Gronovioideae inferred from $\mathrm{mat} K$ and ITS sequence data. Amer. J. Bot. 88:326-336.

O'Kane S.L., B.A. Schaal, and I.A. Al-Shehbaz. 1996. The origin of Arabidopsis suecica (Brassicaceae) as indicated by nuclear rDNA sequences. Syst. Bot. 21:559-566.

Richard, A.J. 1990a. Studies in Garcinia, dioecious tropical forest trees: agamospermy. Bot. J. Linn. Soc. 103:233-250.

Richard, A.J. 1990b. Studies in Garcinia, dioecious tropical forest trees: the origin of the mangosteen (G. mangostana L.). Bot. J. Linn. Soc. 103:301-308.

Ridley, H.N. 1922. The flora of the Malay Peninsula. vol. 1. Polyupetalae. L. Reeve \& Co. 6, Henrietta Street, Covent Garden, London.

Sang, T., D.J.Crawford, and T.F. Stuessy. 1995. Documentation of reticulate evolution in peonies (Paeonia) using internal transcribed spacer sequences of nuclear ribosomal DNA: Implications for biogeography and concerted evolution. Proc. Natl. Acad. Sci. USA 92:6813-6817.
Saitou, N. and M. Nei. 1987. The neighbour-joining methods: A new method for reconstructing phylogenetic trees. Mol. Biol. Evol. 4: 406-425.

Schnell, R.J., C.M. Ronning, and R.J. Knight, Jr. 1995. Identification of cultivars and validation of genetic relationships in Mangifera indica L. using RAPD markers. Theor. Appl. Genet. 90:269-274.

Smitinand, T. 1980. Thai plant names (botanical names-vernacular name). Royal Forest Dept., Bangkok. (in Thai)

Swofford, D.L. 2002. PAUP*: Phylogenetic analysis using parsimony (*and other methods). Version 4. Sinauer Associates, Sunderland, Mass.

White, T.J., T. Bruns, S. Lee, and J. Taylor. 1990. Amplification and direct sequencing of fungal ribosomal RNA genes for phylogenetics, p. 315-322. In: M. A. Innis, D. H. Gelfand, J. J. Sninsky, and T. J. White (eds.). PCR protocols: A guide to methods and applications. Academic Press, San Diego, Calif.

Yaacob, O. and H.D. Tindall. 1995. Mangosteen cultivation. FAO Plant Production and Protection Paper No. 129.

Yapwattanaphun, C., S. Subhadrabandhu, A. Sugiura, K. Yonemori, and N. Utsunomiya. 2002. Utilization of some Garcinia species in Thailand. Acta Hort. 575:563-570.

Yapwattanaphun, C., S. Kanzaki, K. Yonemori, and S. Subhadrabandhu. 2003. Genetic variation among mangosteens (Garcinia mangostana L.) revealed by AFLP analysis. Thai J. Agr. Sci. 36:329-337.

Yonemori K, C. Honsho, S. Kanzaki, W. Eiadthong, and A. Sugiura. 2002. Phylogenetic relationships of Mangifera species revealed by ITS sequences of nuclear ribosomal DNA and possibility of their hybrid origin. Plant Syst. Evol. 231:59-75. 